Article

\title{
Positive Effects of Impregnation of Fe-oxide in Mesoporous Al-Oxides on the Decontamination of Dimethyl Methylphosphonate
}

\author{
Tae Gyun Woo ${ }^{1,+}$, Byeong Jun Cha ${ }^{1,+}$, Young Dok Kim ${ }^{1, *(D)}$ and Hyun Ook Seo ${ }^{2, *}$ \\ 1 Department of Chemistry, Sungkyunkwan University, Suwon 16419, Korea; tkwoo21@gmail.com (T.G.W.); \\ ckqudwns223@gmail.com (B.J.C.) \\ 2 Department of Chemistry and Energy Engineering, Sangmyung University, Seoul 03016, Korea \\ * Correspondence: ydkim91@skku.edu (Y.D.K.); hyun.ook.seo@smu.ac.kr (H.O.S.); \\ Tel.: +82-31-299-4564 (Y.D.K.); +82-2-2287-6105 (H.O.S.) \\ + These authors equally contributed to this work.
}

Received: 27 September 2019; Accepted: 25 October 2019; Published: 28 October 2019

\begin{abstract}
Dimethyl methylphosphonate (DMMP) is an important simulant of organophosphates pesticides and chemical warfare nerve agents. Here, we investigated the catalytic decontamination of DMMP on Fe-oxide impregnated mesoporous $\mathrm{Al}_{2} \mathrm{O}_{3}$. Fe-oxide $/ \mathrm{Al}_{2} \mathrm{O}_{3}$ sample was prepared via the temperature regulated chemical vapor deposition of Fe-oxide on mesoporous $\mathrm{Al}_{2} \mathrm{O}_{3}$ and post-annealing at $750{ }^{\circ} \mathrm{C}$. The Fe-oxide/ $\mathrm{Al}_{2} \mathrm{O}_{3}$ and bare $\mathrm{Al}_{2} \mathrm{O}_{3}$ samples were exposed to DMMP-containing dry air at room temperature to study the effects of Fe-oxide impregnation on the reactive adsorption of DMMP. The facilitation of DMMP degradation into $\mathrm{CO}_{2}$ and methanol at room temperature in the presence of nano-dispersed Fe-oxide was evidenced by gas-chromatograph and Fourier transform-infrared (FT-IR) absorption spectroscopy. In addition, temperature programmed oxidation (TPO) experiments and gas chromatography (Agilent, 6890) equipped with mass spectrometer (Agilent, 5973N) (GC/MS) analyses revealed that the minimum temperature that was required for total oxidation of $\mathrm{DMMP}$ into $\mathrm{CO}_{2}$ can also be lowered by Fe-oxide impregnation in mesoporous $\mathrm{Al}_{2} \mathrm{O}_{3}$.
\end{abstract}

Keywords: Fe-oxide; mesoporous $\mathrm{Al}_{2} \mathrm{O}_{3}$; dimethyl methylphosphonate; catalytic decontamination

\section{Introduction}

Organophosphates (OPs) are organophosphorus compounds that contain the $\mathrm{O}=\mathrm{P}(\mathrm{OR})_{3}$ functional group and they have been widely used in the agricultural sector as pesticides [1,2]. Many of OPs can be toxic to human and animals, including insects and parasites, and the structure of OPs are also related to the chemical warfare agents (CWAs), such as sarin, VX, GA, and GB [3]. There has been a great interest in developing efficient technique of decontamination of harmful OPs from water, soil, and air. Dimethyl methylphosphonate (DMMP) is one of the most widely used simulants of OPs, since it is structurally similar to toxic OPs, including CWAs, but are relatively nontoxic [4-7].

The adsorption and decomposition of gaseous DMMP molecules on various metal oxides, such as $\mathrm{SiO}_{2}, \mathrm{Al}_{2} \mathrm{O}_{3}, \mathrm{MgO}, \mathrm{La}_{2} \mathrm{O}_{3}$, and $\mathrm{Fe}_{2} \mathrm{O}_{3}$, have been investigated by numerous research groups [4,8-13]. Besides, the mixed structure of different metal oxides (or supported metal oxides) and nano-sized metal oxides have been also examined for the decontamination of DMMP molecules [14-19], and, recently, the utilization of photo-catalysts has been also suggested [20,21].

The chemical nature as well as geometrical structure of metal oxides (porosity and surface area) can influence the adsorption behaviors of DMMP, for instance, the surface-bound hydroxyl groups and Lewis acidity of metal oxides surface can play an important role in determining the adsorption 
behaviors of DMMP on various metal oxides. On most of metal oxides surfaces, DMMP adsorption begins with binding of $\mathrm{P}=\mathrm{O}$ moiety of DMMP at an acidic site on metal oxides. Afterwards, it is followed by preferential elimination of the methoxy groups by nucleophilic attack of surface-bound hydroxyl groups, whereas $\mathrm{P}-\mathrm{CH}_{3}$ bonding were more resistant to bond breaking and generally remained intact on the metal oxide surface [10-12,22,23].

On the other hand, it has been reported that adsorbed DMMP underwent a somewhat different series of events on the surface of iron oxides. No preferential loss of methoxy groups of DMMP $\left(\mathrm{P}-\mathrm{O}-\mathrm{CH}_{3}\right)$ over methyl group $\left(\mathrm{P}-\mathrm{CH}_{3}\right)$ was observed for the case of iron oxides by many research groups $[10,14,15]$. It implied that Fe-oxide surface can promote the $\mathrm{P}-\mathrm{CH}_{3}$ bond breaking, which can be related to the ability of $\mathrm{Fe}(\mathrm{III}) / \mathrm{Fe}(\mathrm{II})$ redox coupling or accommodation of multiple oxidation states of Fe-oxide $[10,14,15]$. This unique ability of Fe-oxide being able to promote the cleavage of $\mathrm{P}-\mathrm{CH}_{3}$, as well as $\mathrm{P}-\mathrm{O}-\mathrm{CH}_{3}$ bonds of DMMP molecule demonstrated by previous studies $[10,14,15]$, makes Fe-oxide a potential candidate material in developing catalysts for DMMP decontamination. However, there was a certain gap that exists in the experimental conditions of DMMP exposure between previous studies and real application.

In the present work, in an attempt to prove the potential of utilization of Fe-oxides in developing efficient catalytic materials for DMMP decontamination, we investigated the effects of Fe-oxide impregnation on porous alumina on the decontamination of DMMP in more realistic conditions (ambient pressure, continuous exposure of DMMP containing air, room temperature). The Fe-oxides were impregnated in mesoporous $\mathrm{Al}_{2} \mathrm{O}_{3}$ via a TR-CVD of Fe-oxide on $\mathrm{Al}_{2} \mathrm{O}_{3}$, followed by thermal annealing at $750{ }^{\circ} \mathrm{C}$. The prepared Fe-oxide $/ \mathrm{Al}_{2} \mathrm{O}_{3}$ sample and bare $\mathrm{Al}_{2} \mathrm{O}_{3}$ were exposed to DMMP containing dry air at room temperature and the effects of Fe-oxide impregnation in mesoporous $\mathrm{Al}_{2} \mathrm{O}_{3}$ on the decontamination of DMMP were investigated while using various analysis techniques, such as gas chromatography (GC), Fourier transform-infrared (FT-IR), Temperature Programmed Oxidation (TPO), and gas chromatography (Agilent, 6890) equipped with mass spectrometer (Agilent, 5973N) (GC/MS). DMMP adsorption and degradation on the Fe-oxide/ $/ \mathrm{Al}_{2} \mathrm{O}_{3}$ sample and bare $\mathrm{Al}_{2} \mathrm{O}_{3}$ at room temperature were examined by means of GC connected to a flow type reactor and FT-IR absorption spectroscopy. The degradation behaviors of DMMP adsorbed on both samples surfaces at elevated temperature were further examined by conducting TPO experiments with a combination of the solid phase microextraction (SPME) method and GC/MS analysis.

\section{Results and Discussion}

\subsection{Characterization Results}

A STEM image and STEM-EDS mapping images of $\mathrm{Fe}, \mathrm{Al}$, and $\mathrm{O}$ elements were measured at the sample position of Fe-oxide/ $\mathrm{Al}_{2} \mathrm{O}_{3}$ particles and they indicate that the Fe atoms were evenly distributed on $\mathrm{Al}_{2} \mathrm{O}_{3}$ particles (Figure 1a-d). Figure 1e shows a Fe 2 $\mathrm{p}_{3 / 2}$ core-level X-ray photoelectron spectrum (XPS) of Fe-oxide $/ \mathrm{Al}_{2} \mathrm{O}_{3}$ and a broad peak extended from 715 to $706 \mathrm{eV}$ was found in the $\mathrm{Fe}$ $2 \mathrm{p}_{3 / 2}$ binding energy region, indicating that distributed Fe atoms in oxidized states. Binding energy position of $\mathrm{Fe} 2 \mathrm{p}_{3 / 2}$ XPS peak can differ upon the oxidation state of Fe-oxides, e.g., $\mathrm{Fe}_{3} \mathrm{O}_{4}(\sim 710.4 \mathrm{eV})$ and $\alpha-\mathrm{Fe}_{3} \mathrm{O}_{4}(\sim 710.4 \mathrm{eV})$. However, the inherent complexity and broadness of Fe $2 \mathrm{p}$ core-level XPS spectrum results from the existence of multiple elements due to the final state relaxation effects prevent us from determining the exact oxidation state of Fe-oxide. It is likely that Fe-oxide consisted of a complex mixture of various oxidized Fe-oxide, such as $\mathrm{Fe}_{3} \mathrm{O}_{4}$ and $\alpha-\mathrm{Fe}_{3} \mathrm{O}_{4}$, which was indicated by our previous analysis on the Fe-oxide/ $\mathrm{Al}_{2} \mathrm{O}_{3}$ sample that was prepared via a similar TR-CVD and post-annealing process by means of Mössbauer spectroscopy [24]. 
a)

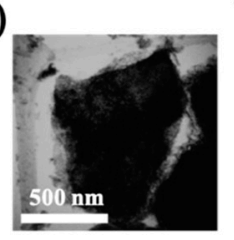

b)

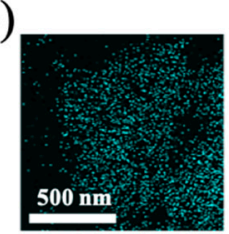

e)

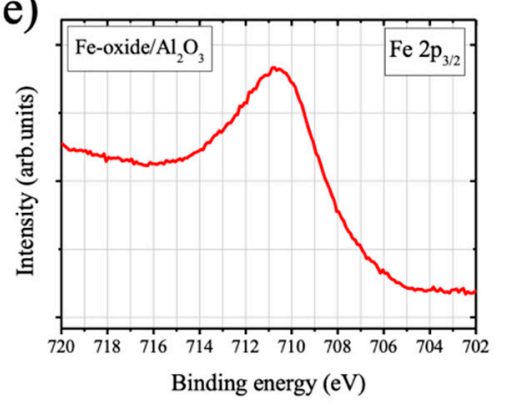

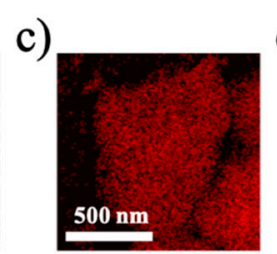

d)

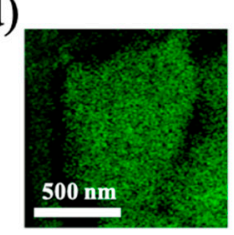

f)

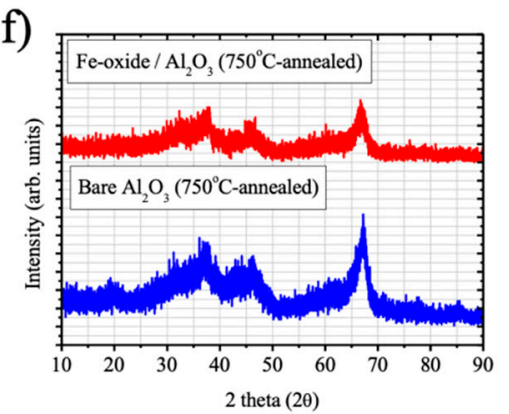

Figure 1. (a) Scanning transmission electron microscopy (STEM) image of Fe-oxide/ $\mathrm{Al}_{2} \mathrm{O}_{3}$ sample and scanning transmission electron microscopy-energy dispersive spectroscopy (STEM-EDS) mapping images of (b) $\mathrm{Fe}$, (c) $\mathrm{Al}$, and (d) $\mathrm{O}$ of $\mathrm{Fe}$-oxide/ $\mathrm{Al}_{2} \mathrm{O}_{3}$ sample are displayed. STEM image and EDS mapping images were taken at same position of Fe-oxide/ $\mathrm{Al}_{2} \mathrm{O}_{3}$ sample. (e) Fe 2 $\mathrm{p}_{3 / 2}$ core-level X-ray photoelectron spectrum (XPS) spectrum of Fe-oxide/ $\mathrm{Al}_{2} \mathrm{O}_{3}$ is shown. (f) XRD patterns of bare $\mathrm{Al}_{2} \mathrm{O}_{3}$ and $\mathrm{Fe}$-oxide $/ \mathrm{Al}_{2} \mathrm{O}_{3}$ are shown.

The crystallinities of bare $\mathrm{Al}_{2} \mathrm{O}_{3}$ and Fe-oxide/ $\mathrm{Al}_{2} \mathrm{O}_{3}$ samples were also studied by measuring their XRD patterns (Figure 1f). A pronounce XRD peak at $67^{\circ}$ was observed with broad feature consist of multiple peaks in the $2 \theta$ range of $20 \sim 50^{\circ}$ for the case of bare $\mathrm{Al}_{2} \mathrm{O}_{3}$, which can be attributed to $\chi$-phase of $\mathrm{Al}_{2} \mathrm{O}_{3}$ [24]. No additional XRD peaks appeared upon the Fe-oxide deposition and subsequent $750{ }^{\circ} \mathrm{C}$-annealing, and the Fe-oxide $/ \mathrm{Al}_{2} \mathrm{O}_{3}$ sample also exhibited very similar XRD patterns with bare $\mathrm{Al}_{2} \mathrm{O}_{3}$, which can be attributed to the small size of Fe-oxide moiety existed in Fe-oxide/ $/ \mathrm{Al}_{2} \mathrm{O}_{3}$. However, it is noticeable that the intensity of the XRD peak at $67^{\circ}$ decreased upon Fe-oxide deposition, followed by $750^{\circ} \mathrm{C}$-annealing, which implies that Fe-oxide deposited on $\mathrm{Al}_{2} \mathrm{O}_{3}$ can disturb the lattice structure of $\mathrm{Al}_{2} \mathrm{O}_{3}$ during the annealing process $\left(750^{\circ} \mathrm{C}, 8 \mathrm{~h}\right)$.

Figure 2 shows the pore size distributions of pristine $\mathrm{Al}_{2} \mathrm{O}_{3}$ (none-annealed), bare $\mathrm{Al}_{2} \mathrm{O}_{3}\left(750{ }^{\circ} \mathrm{C}\right.$ annealed), and Fe-oxide $/ \mathrm{Al}_{2} \mathrm{O}_{3}\left(750^{\circ} \mathrm{C}\right.$ annealed), and Table 1 summarizes their BET specific surface areas and average pore diameters. The pore size distribution curve of pristine $\mathrm{Al}_{2} \mathrm{O}_{3}$ underwent significant changes upon $750{ }^{\circ} \mathrm{C}$-annealing. The average pore diameter $\mathrm{Al}_{2} \mathrm{O}_{3}$ increased from $4.38 \mathrm{~nm}$ to $9.56 \mathrm{~nm}$, accompanied with a decrease of surface area of $\mathrm{Al}_{2} \mathrm{O}_{3}$ (from $334.2 \mathrm{~m}^{2} / \mathrm{g}$ to $138.6 \mathrm{~m}^{2} / \mathrm{g}$ ). These results indicated that the porous structure of pristine $\mathrm{Al}_{2} \mathrm{O}_{3}$ was significantly ruptured upon $750{ }^{\circ} \mathrm{C}$-annealing. Similar phenomenon was observed when the Fe-oxide were deposited on $\mathrm{Al}_{2} \mathrm{O}_{3}$; an increase of average pore diameter from 4.38 to $6.46 \mathrm{~nm}$ and decrease of surface area from 334.2 to $171.8 \mathrm{~m}^{2} / \mathrm{g}$ upon $750^{\circ} \mathrm{C}$-annealing were observed. However, the structural changes due to collapsing of the original porous structure of $\mathrm{Al}_{2} \mathrm{O}_{3}$ upon $750{ }^{\circ} \mathrm{C}$ annealing were less significant when Fe-oxide was deposited on $\mathrm{Al}_{2} \mathrm{O}_{3}$, resulting in higher BET surface area and smaller average pore diameter of Fe-oxide $/ \mathrm{Al}_{2} \mathrm{O}_{3}\left(750^{\circ} \mathrm{C}\right.$-annealed) than bare $\mathrm{Al}_{2} \mathrm{O}_{3}\left(750^{\circ} \mathrm{C}\right.$-annealed) (Figure 2 and Table 1$)$. Those results implied that the thermal stability of the porous structure of $\mathrm{Al}_{2} \mathrm{O}_{3}$ particle can be improved in the presence of TR-CVD deposited Fe-oxide on $\mathrm{Al}_{2} \mathrm{O}_{3}$, which can be attributed to the interaction between Fe-oxide and $\mathrm{Al}_{2} \mathrm{O}_{3}$. 


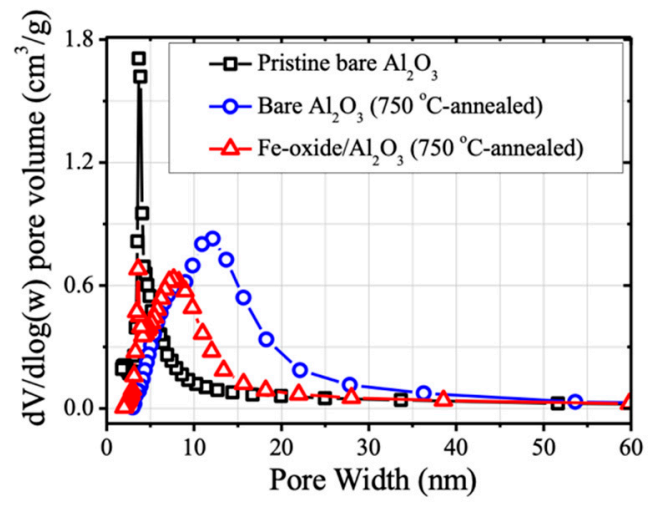

Figure 2. Barrett-Joyner-Halenda $(\mathrm{BJH})$ pore size distributions of pristine $\mathrm{Al}_{2} \mathrm{O}_{3}$ (none-annealed), bare $\mathrm{Al}_{2} \mathrm{O}_{3}\left(750{ }^{\circ} \mathrm{C}\right.$-annealed), and Fe-oxide $/ \mathrm{Al}_{2} \mathrm{O}_{3}\left(750{ }^{\circ} \mathrm{C}\right.$-annealed $)$ are shown.

Table 1. BET specific surface areas and pore diameters of pristine bare $\mathrm{Al}_{2} \mathrm{O}_{3}$ (none-annealed), bare $\mathrm{Al}_{2} \mathrm{O}_{3}\left(750{ }^{\circ} \mathrm{C}\right.$-anneaeld), and $\mathrm{Fe}$-oxide $/ \mathrm{Al}_{2} \mathrm{O}_{3}\left(750{ }^{\circ} \mathrm{C}\right.$-annealed) are summarized with the amount of Fe-loading of Fe-oxide $/ \mathrm{Al}_{2} \mathrm{O}_{3}\left(750{ }^{\circ} \mathrm{C}\right.$-annealed) sample determined by inductively coupled plasma optical emission spectroscopy (ICP-OES).

\begin{tabular}{cccc}
\hline & $\begin{array}{c}\text { BET Surface Area } \\
\left(\mathbf{m}^{\mathbf{2}} / \mathbf{g}\right)\end{array}$ & $\begin{array}{c}\text { Average Pore Diameter } \\
(\mathbf{n m})\end{array}$ & $\begin{array}{c}\text { Fe Loading } \\
\mathbf{( w t} \mathbf{)})\end{array}$ \\
\hline $\begin{array}{c}\text { Pristine bare } \mathrm{Al}_{2} \mathrm{O}_{3} \\
(\text { none-annealed) }\end{array}$ & 334.2 & 4.38 & - \\
\hline $\begin{array}{c}\text { Bare } \mathrm{Al}_{2} \mathrm{O}_{3} \\
\left(750^{\circ} \mathrm{C}-\text {-annealed }\right)\end{array}$ & 138.6 & 9.56 & - \\
\hline $\begin{array}{c}\mathrm{Fe}-\mathrm{oxide} / \mathrm{Al}_{2} \mathrm{O}_{3} \\
\left(750{ }^{\circ} \mathrm{C}-\text {-annealed }\right)\end{array}$ & 171.8 & 6.46 & 10.0 \\
\hline
\end{tabular}

Those are somewhat different situations from our previous studies, where the formation of crystalline Fe-oxide nanoparticles was observed on mesoporous materials via a TR-CVD of Fe-oxide and subsequent thermal annealing [25]. In the previous case, the original pore structure of mesoporous $\mathrm{SiO}_{2}$ was mostly maintained, so that TR-CVD deposited Fe-oxide can be accumulated inside a specific pore generating crystalline Fe-oxide nanoparticles during the post-annealing process [25]. Additionally, it resulted in a decrease of pore volume with a specific size $(\sim 10 \mathrm{~nm})$ of which size was correlated with the diameter $(\sim 10 \mathrm{~nm})$ of crystalline Fe-oxide nanoparticles directly measured by the size of Fe-oxide lattice fringes on TEM images [25].

In contrast, in this case of study, the mesoporous structure $\mathrm{Al}_{2} \mathrm{O}_{3}$ underwent significant changes during the annealing process. Thus, it was likely that the accumulation of Fe-oxide inside a specific size of pore originally existed on pristine $\mathrm{Al}_{2} \mathrm{O}_{3}$ took place. Instead, $\mathrm{Fe}$-oxide might accumulate inside a newly formed pores $(>10 \mathrm{~nm})$ of the $750{ }^{\circ} \mathrm{C}$-annealed sample. However, no indication of the formation of Fe-oxide nanoparticles $(>10 \mathrm{~nm})$ was found by HRTEM and XRD analyses, although the even distribution of $\mathrm{Fe}$ atoms on $\mathrm{Al}_{2} \mathrm{O}_{3}$ was confirmed by STEM-EDS analysis (Figure 1). It is worth mentioning that the formation of Fe-oxide nanoparticles $(\sim 10 \mathrm{~nm})$ was confirmed by TEM and XRD analyses in our previous studies [25]. Therefore, we conclude that Fe-oxide impregnation into mesoporous $\mathrm{Al}_{2} \mathrm{O}_{3}$ took place, rather than specific sized Fe-oxide nanoparticles forming by accumulation of temperature regulated chemical vapor deposition (TR-CVD) deposited Fe-oxide inside the pores of $\mathrm{Al}_{2} \mathrm{O}_{3}$.

\subsection{DMMP Exposure at Room Temperature}

DMMP containing dry air (total flow of $50 \mathrm{~mL} / \mathrm{min}$ ) flowed into the SUS reactor that was filled with $2.0 \mathrm{~g}$ of each sample (bare $\mathrm{Al}_{2} \mathrm{O}_{3}$ and Fe-oxide $/ \mathrm{Al}_{2} \mathrm{O}_{3}$ particles) at room temperature and the 
gas that passed through the reactor was analyzed by online GC. Two peaks were detected by online GC at different retention times, one centered at $\sim 4.46 \mathrm{~min}$ and the other one at $\sim 2.27 \mathrm{~min}$, and they corresponded to the DMMP and $\mathrm{CO}_{2}$, respectively. The area of each GC peak was converted to mol-ppm and its change with increasing DMMP exposure time is shown in Figure 3. The grey solid lines in Figure 3 correspond to the blank level of each species measured with empty SUS reactor under the same conditions of gas flow and temperature.

a)

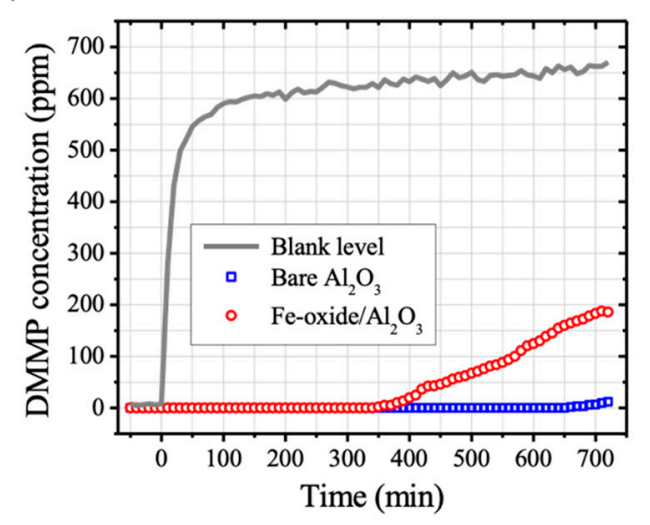

b)

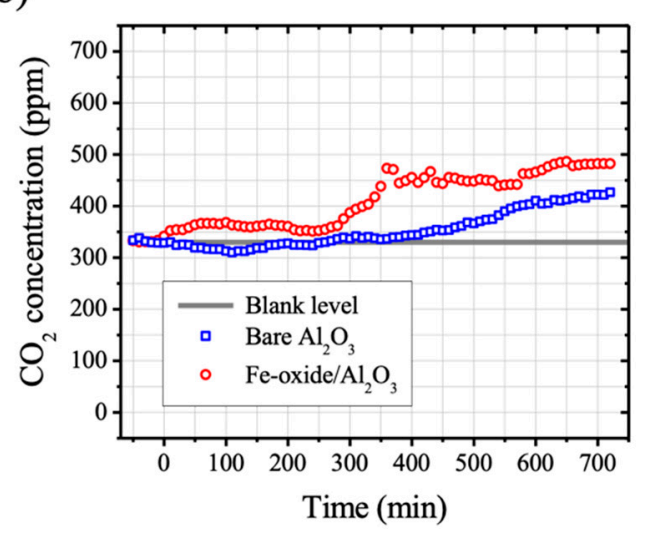

Figure 3. Concentration changes of (a) dimethyl methylphosphonate (DMMP) and (b) $\mathrm{CO}_{2}$ in the gas passed through the empty SUS reactor (solid gray lines), the reactor filled with bare $\mathrm{Al}_{2} \mathrm{O}_{3}$ (empty blue squares) and Fe-oxide/ $\mathrm{Al}_{2} \mathrm{O}_{3}$ (empty red circles) are displayed as a function of DMMP exposing time.

Figure $3 a$ shows the DMMP breakthrough curves of bare $\mathrm{Al}_{2} \mathrm{O}_{3}$ and Fe-oxide $/ \mathrm{Al}_{2} \mathrm{O}_{3}$. The breakthrough times of bare $\mathrm{Al}_{2} \mathrm{O}_{3}$ and Fe-oxide/ $\mathrm{Al}_{2} \mathrm{O}_{3}$ where the DMMP concentration at effluent gas was higher than 1 percent of the blank level were determined to be $710 \mathrm{~min}$ and $380 \mathrm{~min}$, respectively (Table 2). For both cases of bare $\mathrm{Al}_{2} \mathrm{O}_{3}$ and Fe-oxide $/ \mathrm{Al}_{2} \mathrm{O}_{3}$, increases of $\mathrm{CO}_{2}$ level as a function of exposure time were observed before the respective breakthrough time, which implies that the degradation of DMMP molecules occurred on both samples surface at room temperature (Figure $3 b$ ). There were certain induction periods of gaseous $\mathrm{CO}_{2}$ evolution from the surfaces of both samples, and Fe-oxide $/ \mathrm{Al}_{2} \mathrm{O}_{3}$ exhibited shorter induction time when compared to the bare $\mathrm{Al}_{2} \mathrm{O}_{3}$ (Figure $3 \mathrm{~b}$ ). The time when more than $20 \%$ of increase from the blank level of $\mathrm{CO}_{2}$ concentration $(330 \mathrm{ppm})$ was found was taken as an induction time since there was a fluctuation of $\mathrm{CO}_{2}$ concentration level ( $\pm 9 \%)$ under our experimental conditions. The induction time of Fe-oxide $/ \mathrm{Al}_{2} \mathrm{O}_{3}$ for gaseous $\mathrm{CO}_{2}$ was determined to be $310 \mathrm{~min}$, whereas that of bare $\mathrm{Al}_{2} \mathrm{O}_{3}$ was determined to be $560 \mathrm{~min}$ (Table 2). 
Table 2. DMMP breakthrough time and $\mathrm{CO}_{2}$ induction time of bare $\mathrm{Al}_{2} \mathrm{O}_{3}$ and Fe-oxide $/ \mathrm{Al}_{2} \mathrm{O}_{3}$ are summarized.

\begin{tabular}{ccc}
\hline & $\begin{array}{c}\text { DMMP } \\
\text { Breakthrough Time } \\
\text { (min) }\end{array}$ & $\begin{array}{c}\mathrm{CO}_{2} \\
\text { Induction Time } \\
\text { (min) }\end{array}$ \\
\hline $\begin{array}{c}\text { Bare } \mathrm{Al}_{2} \mathrm{O}_{3} \\
(\text { none-annealed })\end{array}$ & 710 & 560 \\
\hline $\begin{array}{c}\mathrm{Fe}-\mathrm{oxide} / \mathrm{Al}_{2} \mathrm{O}_{3} \\
\left(750^{\circ} \mathrm{C} \text {-annealed }\right)\end{array}$ & 380 & 310 \\
\hline
\end{tabular}

Gaseous $\mathrm{CO}_{2}$ evolution from the metal-oxide surface at room temperature has been previously reported $[11,16,17,26]$, and the relationship between the induction period of $\mathrm{CO}_{2}$ evolution and surface area has been suggested; the higher the surface area, the longer the $\mathrm{CO}_{2}$ induction time [16,17]. However, in our case of study, the different induction time for $\mathrm{CO}_{2}$ evolution between two samples (bare $\mathrm{Al}_{2} \mathrm{O}_{3}$ and Fe-oxide $/ \mathrm{Al}_{2} \mathrm{O}_{3}$ ) was not likely attributed to the difference in surface area. Fe-oxide $/ \mathrm{Al}_{2} \mathrm{O}_{3}$ with higher surface area $\left(171.8 \mathrm{~m}^{2} / \mathrm{g}\right)$ exhibited shorter $\mathrm{CO}_{2}$ induction time $(310 \mathrm{~min})$ than bare $\mathrm{Al}_{2} \mathrm{O}_{3}$ (560 $\mathrm{min}$ ) with lower surface area $\left(138.6 \mathrm{~m}^{2} / \mathrm{g}\right)$ in this study. Alternatively, the shorter induction $\mathrm{CO}_{2}$ time of Fe-oxide/ $/ \mathrm{Al}_{2} \mathrm{O}_{3}$ samples than that of bare $\mathrm{Al}_{2} \mathrm{O}_{3}$ can be attributed to the co-existence of Fe-oxides and $\mathrm{Al}$-oxides, which can provide additional sites being able to facilitate DMMP degradation.

\subsection{IR Analysis}

The surface of each sample (bare $\mathrm{Al}_{2} \mathrm{O}_{3}$ and Fe-oxide $/ \mathrm{Al}_{2} \mathrm{O}_{3}$ ) before and after DMMP exposure at room temperature was analyzed by means of IR absorption spectroscopy in order to understand different behaviors of bare $\mathrm{Al}_{2} \mathrm{O}_{3}$ and Fe-oxide/ $\mathrm{Al}_{2} \mathrm{O}_{3}$ observed during the DMMP exposure experiments at room temperature (Figure 4). The conditions of DMMP exposure to prepare the samples for IR analysis were same as those of the aforementioned DMMP exposure experiments. However, the DMMP exposure time was reduced to $360 \mathrm{~min}$ from $720 \mathrm{~min}$, i.e., DMMP exposure was ended before the DMMP breakthrough times of both samples (Table 1) to keep the amount of adsorbed DMMP on both samples surface at same level. Figure 4 shows the IR absorption spectra of bare $\mathrm{Al}_{2} \mathrm{O}_{3}$ and Fe-oxide/ $\mathrm{Al}_{2} \mathrm{O}_{3}$ measured before and after the DMMP exposure. The spectra are displayed in two wavenumber ranges (lower wavenumber range of $900-1500 \mathrm{~cm}^{-1}$ and higher wavenumber range of $2400-3800 \mathrm{~cm}^{-1}$ ), respectively, and they were only vertically shifted without background subtraction. Background subtracted IR spectra in higher wavenumber range are additionally provided in the supplementary material Figure S1.

Upon the DMMP exposure at room temperature, appearances of characteristic IR absorption peaks of DMMP molecules were observed on the bare $\mathrm{Al}_{2} \mathrm{O}_{3}$ samples, which were $\mathrm{P}_{-}-\mathrm{CH}_{3}$ deformation $\left(\sim 1315 \mathrm{~cm}^{-1}\right), \mathrm{P}=\mathrm{O}$ stretching $\left(\sim 1215 \mathrm{~cm}^{-1}\right), \mathrm{O}-\mathrm{CH}_{3}$ deformation $\left(\sim 1181 \mathrm{~cm}^{-1}\right)$, and asymmetric and symmetric stretching of $\mathrm{C}-\mathrm{O}\left(\sim 1065\right.$ and $1045 \mathrm{~cm}^{-1}$, respectively) (Figure 4a) [22]. Apart from the appearances of characteristic DMMP peaks, other changes were not noticeable for the case of bare $\mathrm{Al}_{2} \mathrm{O}_{3}$ upon the DMMP exposure. It has been reported that the DMMP adsorption on aluminum oxide took place via an electrophilic attack of the surface on DMMP [10]; the $\mathrm{P}=\mathrm{O}$ bond of DMMP molecule interacts with coordinatively unsaturated aluminum (Lewis acid) sites and phosphoryl group of DMMP molecule interacts with a surface hydroxyl group (Figure 5). Subsequently, it was followed by the loss of one methoxy group from surface-bound DMMP molecule, leaving a surface-bridging methyl methylphosphonate (MMP) on the surface [10]. As temperature increases, the other methoxy group remained at MMP can be lost, forming a surface-bound methylphosphonate (MP). The formation of surface-bound MMP and MP was evidenced by the shift of $\mathrm{P}=\mathrm{O}$ stretching vibration towards lower wavenumber from $1216 \mathrm{~cm}^{-1}$ to $\sim 1190 \mathrm{~cm}^{-1}$ [10]. However, in our case of study, it is not clear whether the surface-bound MMP or MP was formed on bare $\mathrm{Al}_{2} \mathrm{O}_{3}$ surface under our experimental conditions, 
since the reported IR absorption peak position of surface-bound MMP and MP was very close to the peak of $\mathrm{O}-\mathrm{CH}_{3}$ deformation $\left(\sim 1181 \mathrm{~cm}^{-1}\right)$.

a)

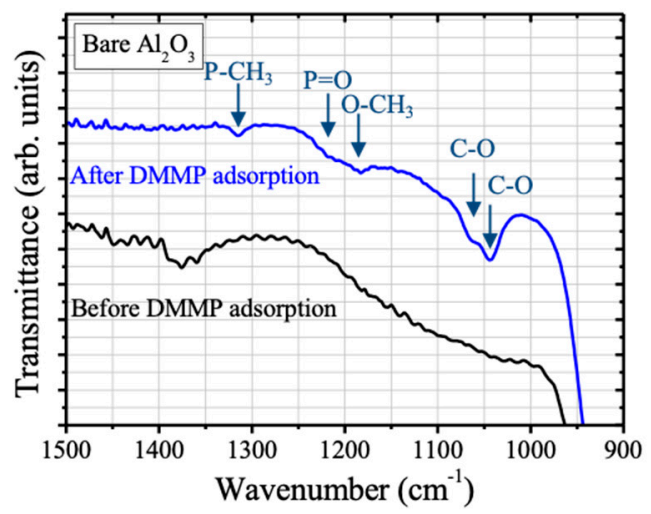

c)

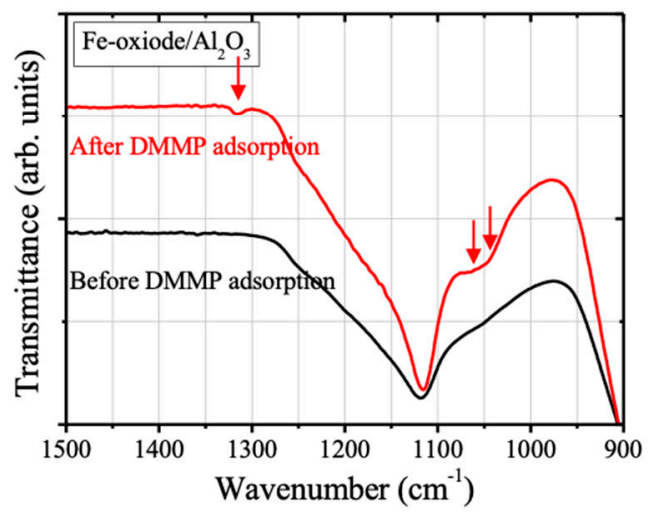

b)

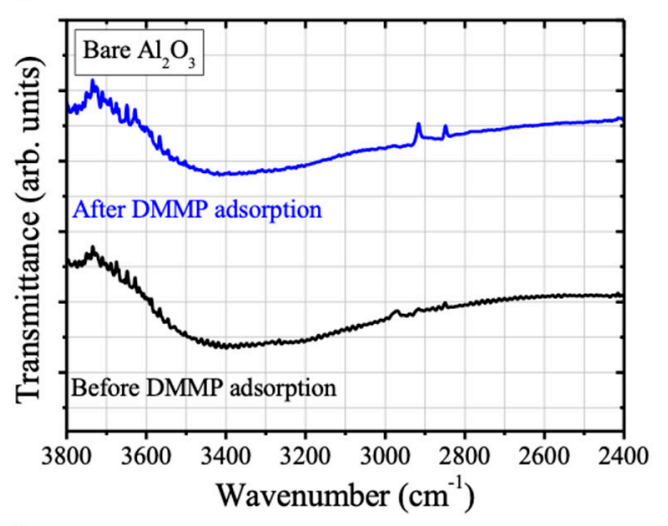

d)

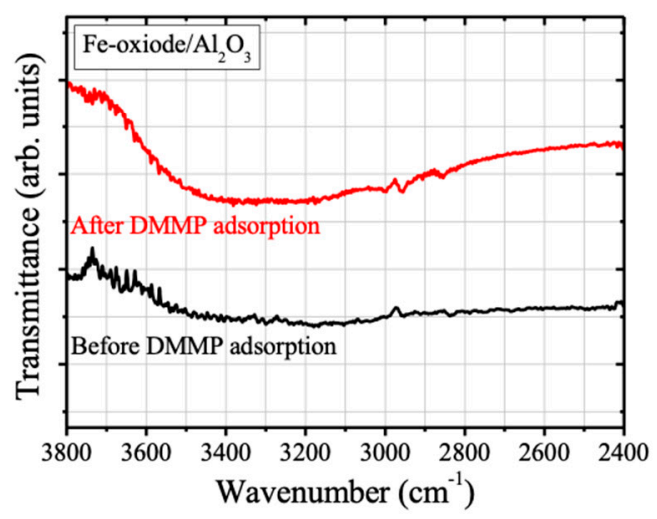

Figure 4. Fourier transform-infrared (FT-IR) spectra of $(\mathbf{a}, \mathbf{b})$ bare $\mathrm{Al}_{2} \mathrm{O}_{3}$ and $(\mathbf{c}, \mathbf{d})$ Fe-oxide $/ \mathrm{Al}_{2} \mathrm{O}_{3}$ before and after $360 \mathrm{~min}$ of DMMP exposure at room temperature in two different wavenumber ranges of $(\mathbf{a}, \mathbf{c})$ 900-1500 $\mathrm{cm}^{-1}$, and (b,d) $2400-3800 \mathrm{~cm}^{-1}$ are shown. Characteristic IR absorption peaks of DMMP molecules are marked by arrows in (a) and (c).

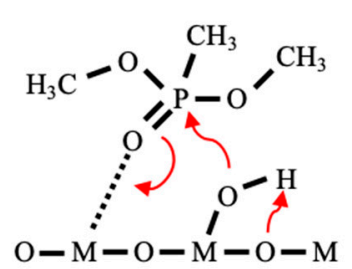

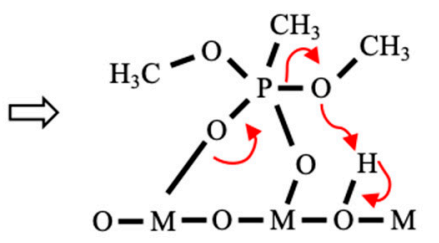<smiles>[M]O[M]O[W](C)(=O)O[W](C)(=O)OC</smiles>

Surface bound methyl methylphosphonate (Surface bound MMP)

$+$

Methanol

Figure 5. A mechanism of reactive DMMP adsorption on metal-oxide surface via an electrophilic attack of the surface on DMMP molecule [10].

Characteristic IR absorption peaks of DMMP molecules were also detected on the surface of Fe-oxide $/ \mathrm{Al}_{2} \mathrm{O}_{3}$ after the DMMP exposure at room temperature, which were $\mathrm{P}-\mathrm{CH}_{3}$ deformation at $\sim 1315 \mathrm{~cm}^{-1}$ and asymmetric and symmetric stretching of $\mathrm{C}-\mathrm{O}$ at $\sim 1065$ and $1045 \mathrm{~cm}^{-1}$, respectively (Figure 4c). However, in contrast to the case of bare $\mathrm{Al}_{2} \mathrm{O}_{3}$ sample, the IR peak at $\sim 1114 \mathrm{~cm}^{-1}$ increased in its intensity and $\mathrm{P}=\mathrm{O}$ stretching $\left(\sim 1215 \mathrm{~cm}^{-1}\right), \mathrm{O}-\mathrm{CH}_{3}$ deformation $\left(\sim 1181 \mathrm{~cm}^{-1}\right)$ peaks of DMMP 
molecules were no longer observable after the DMMP exposure. The peak at $1114 \mathrm{~cm}^{-1}$ existed on the surface of Fe-oxide/ $\mathrm{Al}_{2} \mathrm{O}_{3}$ before the DMMP adsorption was attributed to oxidized carbon impurities ( $\mathrm{C}-\mathrm{O}$ stretching mode), which were likely to be formed on the surface of Fe-oxide $/ \mathrm{Al}_{2} \mathrm{O}_{3}$ during the sample preparation, e.g., oxidation of adsorbed ferrocene molecules. The increase of IR peak intensity at $\sim 1114 \mathrm{~cm}^{-1}$ can be attributed to the $\mathrm{P}=\mathrm{O}$ stretching mode of the surface-bound MMP or MP molecules formed on the surface of Fe-oxide $/ \mathrm{Al}_{2} \mathrm{O}_{3}$ (Figure 4c) during DMMP exposure. The difference in IR absorption peak position of surface-bound MMP or MP species between on the surface of Fe-oxide/ $/ \mathrm{Al}_{2} \mathrm{O}_{3}$ and on previously studied alumina surface can be ascribed to the different nature of the surfaces, e.g., the degree of Lewis acidity of the surfaces or coordination of surface-bound species on the surfaces [10].

Those results indicate that the interaction between DMMP molecules and $\mathrm{Al}_{2} \mathrm{O}_{3}$ surface was enhanced by Fe-oxide impregnation, which facilitated the dissociation of DMMP molecules on the surface formation of surface-bound MMP or MP and methanol species (Figure 5). It is also worth mentioning that surface-bound methanol species can be also formed, which can contribute to the intensity increase of IR absorption peak at $1114 \mathrm{~cm}^{-1}$ (C-O stretching mode of methanol) and increase of $-\mathrm{OH}$ stretching IR band $\left(3600 \sim 3200 \mathrm{~cm}^{-1}\right)$ (Figure 4d) [27]. The surface-bound formate species might also be formed during the DMMP conversion into $\mathrm{CO}_{2}$; however, in our case of study, there was no IR absorption peak that appeared at $1600 \mathrm{~cm}^{-1}$ (antisymmetric COO stretching mode) upon DMMP exposure for both samples (bare $\mathrm{Al}_{2} \mathrm{O}_{3}$, and Fe-oxide $/ \mathrm{Al}_{2} \mathrm{O}_{3}$ ).

Our IR analyses results cannot reveal the detailed mechanisms of the reactive DMMP adsorption on Fe-oxide $/ \mathrm{Al}_{2} \mathrm{O}_{3}$ sample. Additionally, further investigations, e.g., operando FT-IR analyses during the DMMP exposure, are needed to follow the adsorption mechanisms that guarantee another subject of study. For instance, $\mathrm{P}-\mathrm{CH}_{3}$ bond breaking was not evidenced on the surface Fe-oxide $/ \mathrm{Al}_{2} \mathrm{O}_{3}$, which is different from the previously reported study [10], and this discrepancy likely arises from different nature of the sample. The previous study was performed with pure Fe-oxide surface; whereas, we studied Fe-oxide impregnated $\mathrm{Al}_{2} \mathrm{O}_{3}$, where the Fe-Al oxide interface sites as well as two oxidic surface (Fe- and Al-oxide surface) took part in the reactive DMMP adsorption process. However, this cannot be clearly addressed solely based on the presented IR analyses results and it requires further studies. Nevertheless, our experimental observations show that Fe-oxide impregnation in $\mathrm{Al}_{2} \mathrm{O}_{3}$ can promote the dissociation of adsorbed DMMP molecules on the surface, which can facilitate the degradation of DMMP into $\mathrm{CO}_{2}$ on the surface of Fe-oxide/ $\mathrm{Al}_{2} \mathrm{O}_{3}$, which reduces the $\mathrm{CO}_{2}$ induction time (Table 2).

\subsection{Temperature Programmed Oxidation (TPO) Experiments and GC/MS Analysis}

The TPO experiments were performed after $360 \mathrm{~min}$ of DMMP adsorption at room temperature with bare $\mathrm{Al}_{2} \mathrm{O}_{3}$ and Fe-oxide $/ \mathrm{Al}_{2} \mathrm{O}_{3}$. Temperature was linearly increased $\left(1^{\circ} \mathrm{C} / \mathrm{min}\right)$ from the room temperature to $750{ }^{\circ} \mathrm{C}$ at a constant dry air flow $(50 \mathrm{~mL} / \mathrm{min})$ and the gaseous species evolved from sample surface was analyzed by online GC. During the TPO experiments, only one GC peak was detected around at $\sim 2.27 \mathrm{~min}$ and no other GC peaks, including a DMMP peak (at $\sim 4.46 \mathrm{~min}$ ), were detected.

Figure $6 \mathrm{a}$ and $\mathrm{b}$ show the GC peak area as a function of temperature during TPO for either case of bare $\mathrm{Al}_{2} \mathrm{O}_{3}$ or Fe-oxide/ $\mathrm{Al}_{2} \mathrm{O}_{3}$. The $y$-axis values (GC peak area) of Figure $6 \mathrm{a}, \mathrm{b}$ are displayed in same $Y$-axis scale, thus a direct comparison of the GC peak area value between bare $\mathrm{Al}_{2} \mathrm{O}_{3}$ and Fe-oxide $/ \mathrm{Al}_{2} \mathrm{O}_{3}$ is possible, although they are displayed in arbitrary units. 
a)

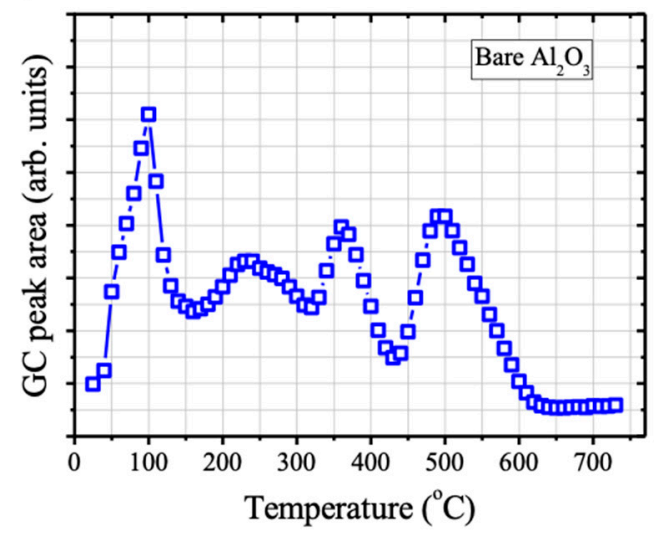

c)

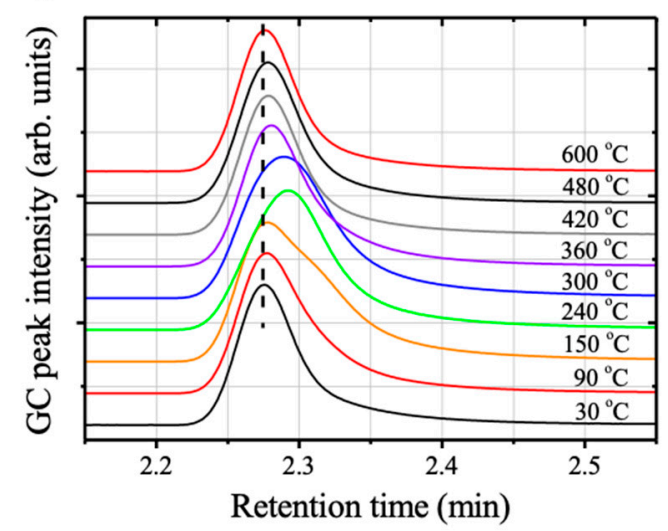

e)

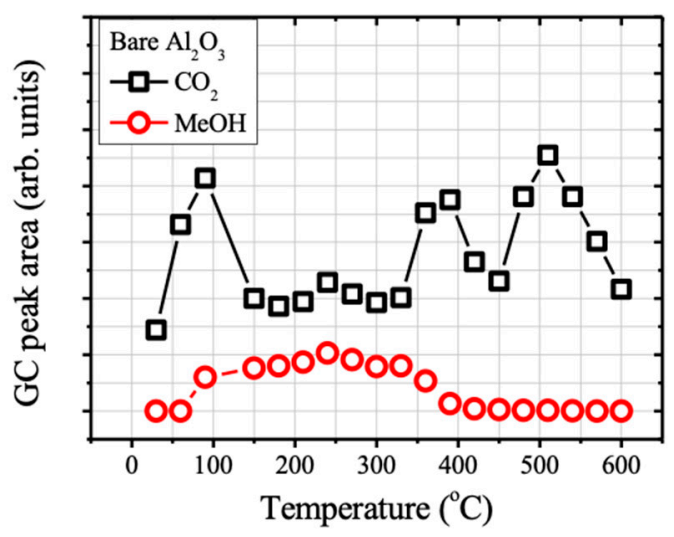

b)

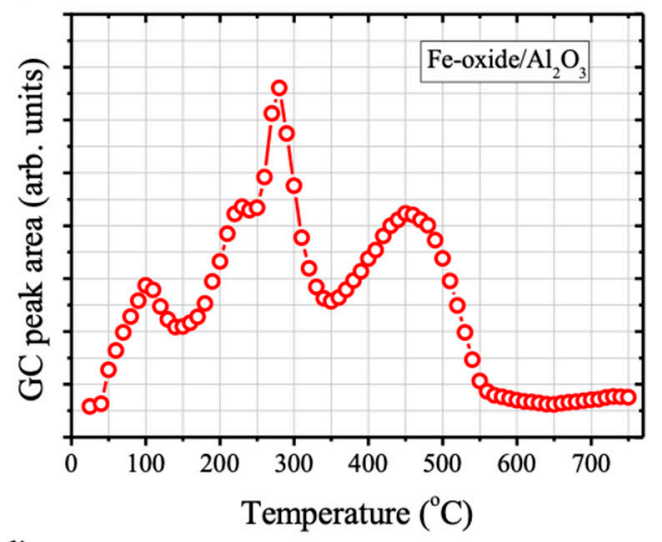

d)

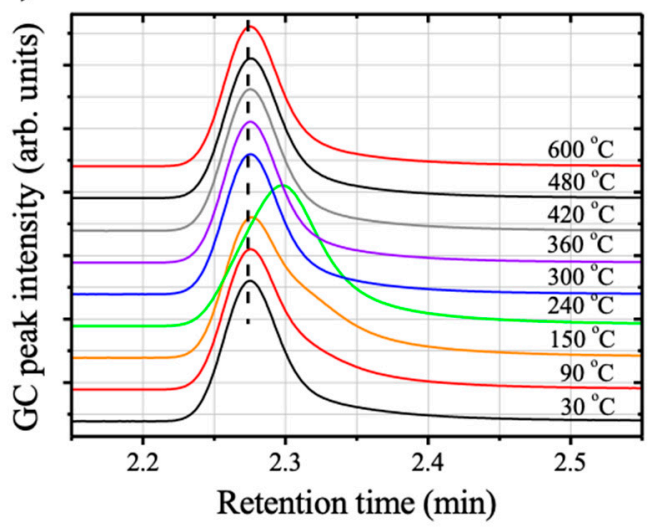

f)

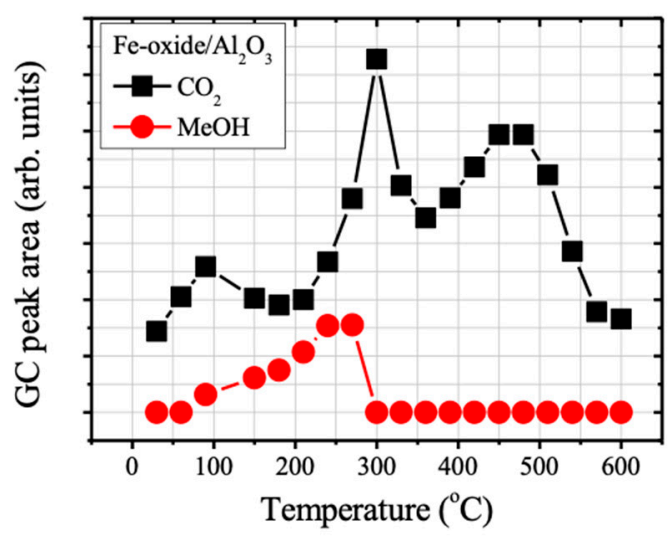

Figure 6. Gas chromatography (GC) peak area of Temperature Programmed Oxidation (TPO) experiments are displayed as a function of temperature for either case of (a) bare $\mathrm{Al}_{2} \mathrm{O}_{3}$ or (b) Fe-oxide $/ \mathrm{Al}_{2} \mathrm{O}_{3}$. GC peaks of TPO experiments measured at various temperatures are displayed for either case of (c) bare $\mathrm{Al}_{2} \mathrm{O}_{3}$ or (d) Fe-oxide $/ \mathrm{Al}_{2} \mathrm{O}_{3}$. The peak height of each GC peak was normalized to that of the respective GC peak obtained with each sample at $30^{\circ} \mathrm{C}$ and the normalized GC spectra were vertically shifted for comparison. Deconvolution results of the GC peaks of TPO at various temperatures are displayed as a function of temperature of TPO experiments for the case of (e) bare $\mathrm{Al}_{2} \mathrm{O}_{3}$ and (f) Fe-oxide/ $\mathrm{Al}_{2} \mathrm{O}_{3}$. The $y$-axis values of graphs in left- and right- column are displayed in same $Y$-axis scale, thus the GC peak area values between bare $\mathrm{Al}_{2} \mathrm{O}_{3}$ and Fe-oxide $/ \mathrm{Al}_{2} \mathrm{O}_{3}$ can be directly compared. 
The peak around at 2.27 min can be tentatively assigned to gaseous $\mathrm{CO}_{2}$ generated by DMMP decomposition during TPO, and, at a first glance, $\mathrm{CO}_{2}$ evolution due to DMMP degradation at low temperature region $\left(<200{ }^{\circ} \mathrm{C}\right)$ was pronounced on the surface of bare $\mathrm{Al}_{2} \mathrm{O}_{3}$ than Fe-oxide $/ \mathrm{Al}_{2} \mathrm{O}_{3}$ (Figure $6 \mathrm{a}, \mathrm{b}$ ). Thus, one might come to the conclusion that the bare $\mathrm{Al}_{2} \mathrm{O}_{3}$ surface was more active for DMMP degradation at a lower temperature region $\left(<200^{\circ} \mathrm{C}\right)$ when compared to the surface of Fe-oxide/ $\mathrm{Al}_{2} \mathrm{O}_{3}$. Additionally, it is not correlated to the afore-discussed results (Figure $3 \mathrm{~b}$, Table 2, and Figure 4), implying a facilitation of DMMP degradation into $\mathrm{CO}_{2}$ or methanol in the presence of Fe-oxide on $\mathrm{Al}_{2} \mathrm{O}_{3}$ surface at room temperature.

However, it should be noted that, on the surface of Fe-oxide/ $\mathrm{Al}_{2} \mathrm{O}_{3}$, gaseous $\mathrm{CO}_{2}$ evolution and methanol generation resulted from DMMP degradation already took place during the $360 \mathrm{~min}$ of DMMP adsorption conducted before the TPO experiments, as pointed out by the aforementioned experimental results (Figure 3, Table 2, and Figure 4). Whereas both the $\mathrm{CO}_{2}$ evolution and methanol generation were not evidenced under the same conditions on the surface of bare $\mathrm{Al}_{2} \mathrm{O}_{3}$.

Further on, we carefully examined the GC spectra of TPO experiments in the range of 2.2 2.5 min for both cases of samples (bare $\mathrm{Al}_{2} \mathrm{O}_{3}$ and $\mathrm{Fe}$-oxide/ $/ \mathrm{Al}_{2} \mathrm{O}_{3}$ ), and the changes of shape and position of the GC peaks of TPO were examined (Figure $6 c, d$ ). For the examination of shape and positions of the GC peaks, the peak height of each GC peak was normalized to that of the respective GC peak that was obtained with each sample (bare $\mathrm{Al}_{2} \mathrm{O}_{3}$ or Fe-oxide $/ \mathrm{Al}_{2} \mathrm{O}_{3}$ ) at $30{ }^{\circ} \mathrm{C}$ and the GC spectra were vertically shifted for comparison (Figure $6 c, d$ ).

The GC peaks centering at 2.27 min can be attributed to gaseous $\mathrm{CO}_{2}$, which were observed in the beginning of $\mathrm{TPO}\left(\right.$ at $30^{\circ} \mathrm{C}$ ) for both cases of samples. In the case of bare $\mathrm{Al}_{2} \mathrm{O}_{3}$, a falling edge of the GC peak was extended to a longer retention time as the temperature increased to $90^{\circ} \mathrm{C}$ from $30^{\circ} \mathrm{C}$, attributed to an appearance of additional GC peak at a longer retention time. The extension was more pronounced by a further temperature increase to $150^{\circ} \mathrm{C}$ due to an increase of the additional GC peak component in its intensity, and the contribution of the additional component to the GC spectrum reached its maximum at $\sim 240^{\circ} \mathrm{C}$; the shift of the center peak position of GC peak to a longer retention time was most pronounced at $240{ }^{\circ} \mathrm{C}$. Subsequently, the intensity of additional GC peak component with respect to the $\mathrm{CO}_{2}$ peak gradually decreased as the temperature increased from $240^{\circ} \mathrm{C}$. Finally, the GC spectrum became identical to the original GC spectrum that was measured at $30^{\circ} \mathrm{C}$ when the temperature reached to $600{ }^{\circ} \mathrm{C}$.

The GC spectra of Fe-oxide $/ \mathrm{Al}_{2} \mathrm{O}_{3}$ samples behaved similarly upon the temperature increase during the TPO experiments that were performed under the same conditions. The initiation of GC peak extension to a longer retention time was observed at $90{ }^{\circ} \mathrm{C}$ due to an appearance of additional GC peak at longer time. The intensity of the additional GC peak component gradually increased as the temperature was ramped to $240^{\circ} \mathrm{C}$ and then decreased by a further temperature increase $\left(>240^{\circ} \mathrm{C}\right)$. However, the contribution of the additional GC peak component was decreased much faster when compared to the bare $\mathrm{Al}_{2} \mathrm{O}_{3}$ case. The GC peak of Fe-oxide $/ \mathrm{Al}_{2} \mathrm{O}_{3}$ recovered its original shapes and position at $30^{\circ} \mathrm{C}$ when the temperature reached to $300{ }^{\circ} \mathrm{C}$, whereas a significant shift of the center position of GC peak to a longer time was still found for the case of bare $\mathrm{Al}_{2} \mathrm{O}_{3}$ at $300{ }^{\circ} \mathrm{C}$.

Gaseous molecules evolved from the surface of samples during the TPO experiments were collected by SPME fibers and analyzed by GC/MS in order to identify the chemical species responsible for the additional GC peak component observed during the TPO experiments with Fe-oxide $/ \mathrm{Al}_{2} \mathrm{O}_{3}$ samples. Figure 6 shows the results of GC/MS analysis with $\mathrm{Fe}$-oxide/ $/ \mathrm{Al}_{2} \mathrm{O}_{3}$ samples. The main GC/MS peak was in the retention time range of 1.0 to $2.0 \mathrm{~min}$ (Figure 7a) and it mostly consisted of 18 , 28 , and $32 \mathrm{~m} / \mathrm{z}$ species that were attributed to water vapor, $\mathrm{N}_{2}$, and $\mathrm{O}_{2}$ of ambient air, respectively (Supplementary material Figure S2). Along with species that originated from ambient air adsorption on SPEM fiber, the existence of species corresponding to $44 \mathrm{~m} / \mathrm{z}$ and $31 \mathrm{~m} / \mathrm{z}$ signal in the retention time region of main GC/MS peak were evidenced (Figure $7 \mathrm{~b}, \mathrm{c}$ ). The $44 \mathrm{~m} / \mathrm{z}$ signal that was attributed to $\mathrm{CO}_{2}$, which was originated either from ambient air adsorption or adsorption of $\mathrm{CO}_{2}$ evolved during the TPO experiment. On the other hand, the $31 \mathrm{~m} / \mathrm{z}$ signal that can assigned to methanol did not 
originate from ambient air, since no $31 \mathrm{~m} / \mathrm{z}$ signal was detected by SPME fiber injection exposed to ambient air (Supplementary material Figure S2). The $31 \mathrm{~m} / \mathrm{z}$ signal (methanol) was also found in the main GC/MS peak region measured with bare $\mathrm{Al}_{2} \mathrm{O}_{3}$ samples (Supplementary material Figure S3). Those results allow for us to conclude that gaseous methanol molecules were generated together with $\mathrm{CO}_{2}$ at a certain temperature range of the TPO, resulting in the broadening and shifting of GC peaks.

a)

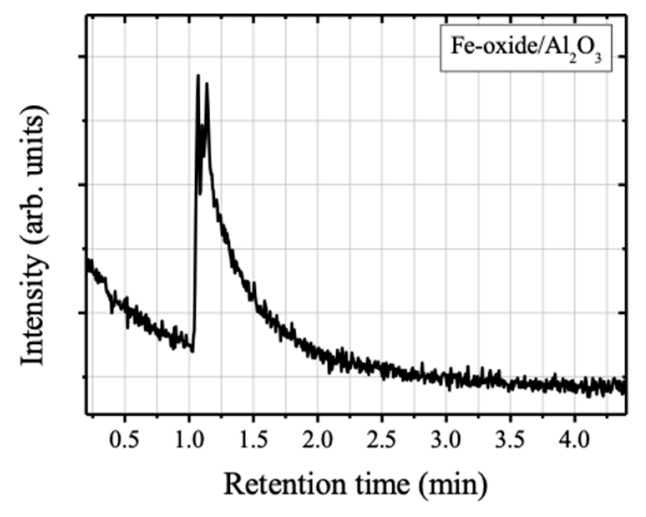

b)

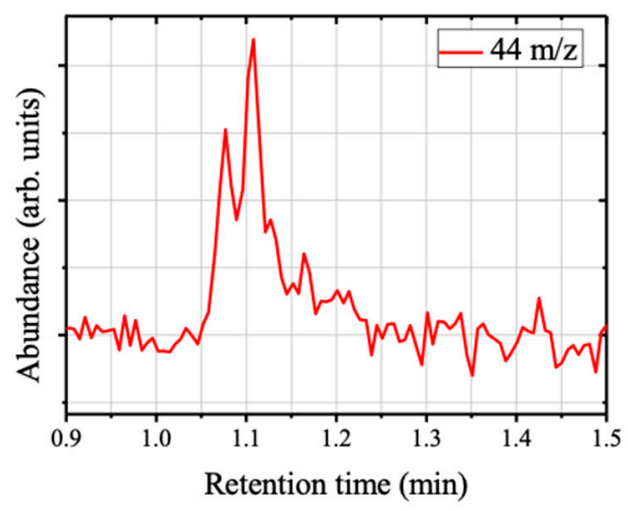

c)

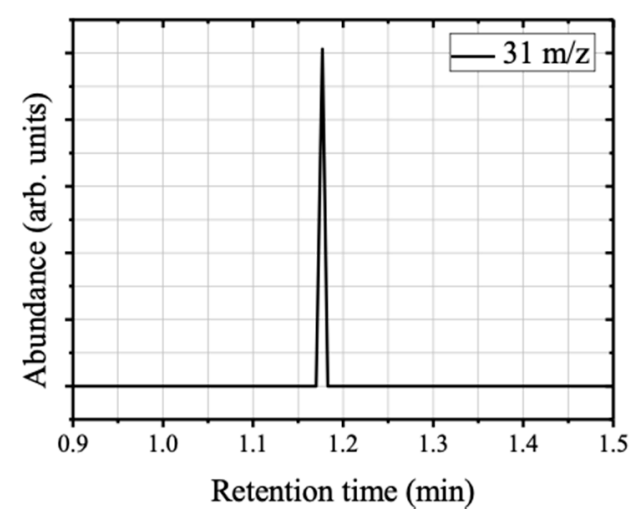

Figure 7. (a) The main gas chromatography (Agilent, 6890) equipped with mass spectrometer (Agilent, $5973 \mathrm{~N}$ ) (GC/MS) peak in the retention time range of 1.0 to 2.0 min obtained with Fe-oxide $/ \mathrm{Al}_{2} \mathrm{O}_{3}$ sample is shown. Intensity of (b) $44 \mathrm{~m} / \mathrm{z}$ and (c) $31 \mathrm{~m} / \mathrm{z}$ signal in the retention time region of the main GC/MS peak obtained with $\mathrm{Fe}$-oxide/ $\mathrm{Al}_{2} \mathrm{O}_{3}$ sample are shown. 
Further on, we deconvolute the GC peaks at various temperatures of TPO experiments while using two components $\left(\mathrm{CO}_{2}\right.$ and methanol components) (Figure 6e,f). During the deconvolution process, only each peak intensity was varied, while the peak position and the peak width at half maximum (FWHM) of each peak were fixed. The deconvolution results show that the temperature window for the evolution of gaseous methanol of Fe-oxide $/ \mathrm{Al}_{2} \mathrm{O}_{3}$ was smaller than that of bare $\mathrm{Al}_{2} \mathrm{O}_{3}$ (Figure $5 \mathrm{e}, \mathrm{f}$ ). In the case of Fe-oxide/ $\mathrm{Al}_{2} \mathrm{O}_{3}$, methanol formation was ended and the most of adsorbed DMMP molecules was converted to $\mathrm{CO}_{2}$ at the temperature at $300{ }^{\circ} \mathrm{C}$. Whereas, still, a significant amount of methanol molecules was evolved from the surface bare $\mathrm{Al}_{2} \mathrm{O}_{3}$ together with $\mathrm{CO}_{2}$ by the degradation of adsorbed DMMP molecules until the temperature reached to $400{ }^{\circ} \mathrm{C}$. It indicated that the minimum temperature required for total oxidation of DMMP molecules to $\mathrm{CO}_{2}$ can be lowered in the presence of Fe-oxides on $\mathrm{Al}_{2} \mathrm{O}_{3}$. Additionally, one can suggest the utilization of Fe-oxide $/ \mathrm{Al}_{2} \mathrm{O}_{3}$ at elevated temperature higher than $300{ }^{\circ} \mathrm{C}$ for a continuous total oxidation of DMMP molecules.

\section{Materials and Methods}

\subsection{Sample Preparation}

The Fe-oxide $/ \mathrm{Al}_{2} \mathrm{O}_{3}$ samples were prepared by a temperature regulated chemical vapor deposition (TR-CVD) of Fe-oxide on mesoporous $\mathrm{Al}_{2} \mathrm{O}_{3}$, followed by a thermal annealing at $750{ }^{\circ} \mathrm{C}$. TR-CVD of Fe-oxide on $\mathrm{Al}_{2} \mathrm{O}_{3}$ particles was carried out using a stainless-steel chamber containing $67.5 \mathrm{~g}$ of bis(cyclopentadienyl)iron $\left(\mathrm{Fe}(\mathrm{Cp})_{2}\right)$ and $100 \mathrm{~g}$ of $\mathrm{Al}_{2} \mathrm{O}_{3}$ particles [24]. The porous $\mathrm{Al}_{2} \mathrm{O}_{3}$ particles (particle size of $2.0 \mathrm{~mm}$ ) were purchased from BASF (Ludwigshafen, Germany) and used as a substrate without a further treatment, while $\mathrm{Fe}(\mathrm{Cp})_{2}$ that was bought from Sigma Aldrich (Saint Louis, $\mathrm{MO}$, USA) was used as a Fe precursor. $\mathrm{Fe}(\mathrm{Cp})_{2}$ powder was placed on the bottom of the chamber (size: $56 \times 37 \times 9 \mathrm{~cm}^{3}$ ) and the $\mathrm{Al}_{2} \mathrm{O}_{3}$ particles were placed $\sim 5 \mathrm{~cm}$ above the chamber bottom while using a stainless-steel mesh container. The outside of the reactor was wrapped with heating bands that were connected to the power supply via a timer (DONGHWA, DH-26). The temperature of the reactor was monitored and controlled using a k-type thermocouple and a temperature control unit (SAMWON ENG., SU-105K). During the TR-CVD process, the reactor temperature was increased by two steps: (1) it was increased to $60^{\circ} \mathrm{C}$ and maintained at $60^{\circ} \mathrm{C}$ for $2 \mathrm{~h}$ and then (2) increased to $200{ }^{\circ} \mathrm{C}$ and maintained at $200^{\circ} \mathrm{C}$ for $12 \mathrm{~h}$. After the TR-CVD process, the Fe-oxide deposited $\mathrm{Al}_{2} \mathrm{O}_{3}$ particles were annealed at $750{ }^{\circ} \mathrm{C}$ for $8 \mathrm{~h}$ under a constant dry air flow of $30 \mathrm{~mL} / \mathrm{min}$ while using a furnace. The bare $\mathrm{Al}_{2} \mathrm{O}_{3}$ particles were also annealed under the same conditions (at $750^{\circ} \mathrm{C}$ for $8 \mathrm{~h}, 30 \mathrm{~mL} / \mathrm{min}$ of dry air flow).

\subsection{Sample Characterization}

Crystallinities of $750{ }^{\circ} \mathrm{C}$-annealed Fe-oxide $/ \mathrm{Al}_{2} \mathrm{O}_{3}$ and $750{ }^{\circ} \mathrm{C}$-annealed bare $\mathrm{Al}_{2} \mathrm{O}_{3}$ were characterized by obtaining $\mathrm{X}$-ray diffraction patterns while using an $\mathrm{X}$-ray diffractometer (Rigaku, Ultima IV, Tokyo, Japan). Cu K $\alpha$ radiation $(40 \mathrm{kV}, 30 \mathrm{~mA}, \lambda=1.54 \AA$ ) was used and a scanning rate was $2 \%$ min. Elemental distribution of $750{ }^{\circ} \mathrm{C}$-annealed Fe-oxide $/ \mathrm{Al}_{2} \mathrm{O}_{3}$ was investigated by means of scanning transmission electron microscopy-energy dispersive spectroscopy (STEM-EDS, JEOL USA Inc., Peabody, MA, USA, JEM-ARM200F). $\mathrm{N}_{2}$ adsorption/desorption isotherms (3Flex, Micromeritics, Norcross, GA, USA) of $750{ }^{\circ} \mathrm{C}$-annealed Fe-oxide/ $/ \mathrm{Al}_{2} \mathrm{O}_{3}$, bare $\mathrm{Al}_{2} \mathrm{O}_{3}$, and $750{ }^{\circ} \mathrm{C}$-annealed bare $\mathrm{Al}_{2} \mathrm{O}_{3}$ were measured. Additionally, their surface areas and pore structures (average pore diameters and pore size distributions) were determined by Brunauer-Emmett-Teller (BET) and Barrett-Joyner-Halenda (BJH) methods, respectively. The inductively coupled plasma optical emission spectroscopy (ICP-OES) was used to determine the amount of Fe loading on $750{ }^{\circ} \mathrm{C}$-annealed Fe-oxide $/ \mathrm{Al}_{2} \mathrm{O}_{3}$ particles. The surfaces of selected samples were analyzed by means of Fourier transform-infrared (FT-IR) absorption spectroscopy while using a FT-IR spectroscopy (ThermoFisher SCIENTIFIC, Nicolet iS10, Waltham, MA, USA). The XPS spectra of Fe-oxide/ $\mathrm{Al}_{2} \mathrm{O}_{3}$ sample were obtained while using an $\mathrm{Mg}$ 
K $\alpha$-line and a concentric hemispherical analyzer (CHA, PHOIBOS-Has 2500, SPECS, Berlin, Germany) at room temperature.

\subsection{DMMP Exposure at Room Temperature}

The DMMP exposing experiment was conducted at room temperature while using a flow-type reactor that was connected to online gas chromatography (GC) (Figure 8a). $\frac{1}{2}$ " SUS (stainless steel) tube was used as a reactor and it was filled with $2.0 \mathrm{~g}$ of each sample $\left(750^{\circ} \mathrm{C}\right.$-annealed bare $\mathrm{Al}_{2} \mathrm{O}_{3}$ or $750{ }^{\circ} \mathrm{C}$-annealed $\mathrm{Fe}$-oxide $/ \mathrm{Al}_{2} \mathrm{O}_{3}$ ). Both ends of the SUS reactor were sealed with stainless steel mesh to keep each $\mathrm{Al}_{2} \mathrm{O}_{3}$ particles inside the reactor during DMMP exposure experiments. All of the experiments discussed in the followings were conducted with $750{ }^{\circ} \mathrm{C}$-annealed bare $\mathrm{Al}_{2} \mathrm{O}_{3}$ and $750{ }^{\circ} \mathrm{C}$-annealed Fe-oxide $/ \mathrm{Al}_{2} \mathrm{O}_{3}$ and, hereafter, they are referred to as bare $\mathrm{Al}_{2} \mathrm{O}_{3}$ and Fe-oxide $/ \mathrm{Al}_{2} \mathrm{O}_{3}$. DMMP-containing dry air (total gas flow rate of $50 \mathrm{~mL} / \mathrm{min}$ ) was flowed into the reactor while using two mass flow controllers (MFC, LINE TECH, M3030V). A bottle containing DMMP was kept at $40{ }^{\circ} \mathrm{C}$ and it was bubbled by dry air at a constant flow rate of $30 \mathrm{~mL} / \mathrm{min}$ while using MFC 2 in Figure $8 \mathrm{a}$. The DMMP gas from the bottle was mixed with dry air flowed at a constant flow rate of $20 \mathrm{~mL} / \mathrm{min}$ using MFC 1 in Figure 8a before it passed through the reactor. Check valves were installed at the gas lines between each MFC and reactor to prevent a possible back stream of the gas (from the reactor to MFC or DMMP bottle). The other side of the reactor was connected to the online gas-chromatography (GC, Hewlett Packard, HP 6890) that was equipped with a capillary column (Agilent Technologies, DB-5, $30 \times 0.32 \mathrm{~mm}$ ), methanizer, and flame ionization detector (FID). All of the gas lines, except, the reactor, consisted of $\frac{1}{4}$ " polytetrafluoroethylene (PTFE) tube and the temperature of gas line was kept at $80^{\circ} \mathrm{C}$ to prevent DMMP adsorption on gas lines. Prior to the DMMP exposure experiments, dry air (50 mL/min, while using MFC 1) containing no DMMP gas was flowed through the reactor until online GC detected no peaks other than $\mathrm{CO} 2$.

\section{a)}

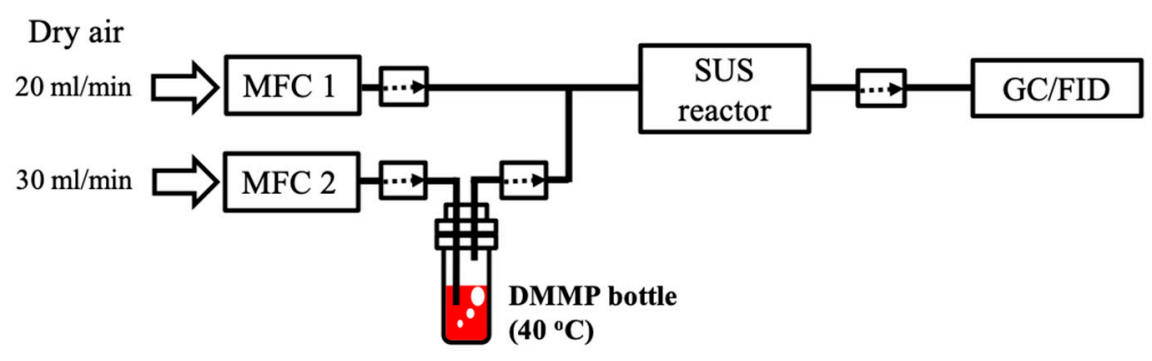

b)

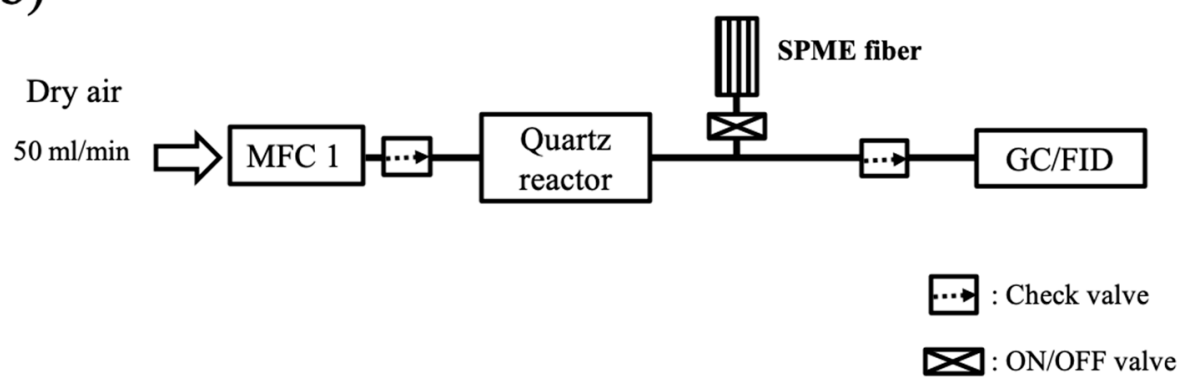

Figure 8. (a) Experimental set-up used for DMMP exposing experiments at room temperature and (b) experimental set-up used for TPO experiments are schematically described. 


\subsection{Temperature Programmed Oxidation (TPO) Experiments and GC/MS Analysis}

After $360 \mathrm{~min}$ of DMMP exposure experiments at room temperature either with $2.0 \mathrm{~g}$ of bare $\mathrm{Al}_{2} \mathrm{O}_{3}$ or Fe-oxide/ $\mathrm{Al}_{2} \mathrm{O}_{3}$ packed inside the SUS reactor, each $\mathrm{Al}_{2} \mathrm{O}_{3}$ particle was collected and transferred to a quartz reactor (inner diameter of $30 \mathrm{~mm}$ ) (Figure $8 \mathrm{~b}$ ). Afterwards, dry air flowed through the quartz reactor at a constant flow rate of $50 \mathrm{~mL} / \mathrm{min}$ while using MFC and the temperature of the reactor containing each $\mathrm{Al}_{2} \mathrm{O}_{3}$ particles increased from the room temperature to $750{ }^{\circ} \mathrm{C}$ at a constant heating rate of $1{ }^{\circ} \mathrm{C} / \mathrm{min}$. Before the initiation of TPO, the reactor was kept at room temperature and flowed by dry air $(50 \mathrm{~mL} / \mathrm{min})$ to remove the weakly bound species from the sample surface. An additional line with an on/off valve was attached to the gas line between the reactor and online GC (Figure 8b), and this line was connected to solid phase microextraction (SPME, SUPELCO 57330-U) fiber. During the TPO process, online GC monitored the gas molecules that evolved from the surface of each $\mathrm{Al}_{2} \mathrm{O}_{3}$ particles and, at the same time, they were accumulatively adsorbed on SPME fiber. The molecules adsorbed on SPME fiber was injected into the gas chromatography (Agilent, 6890) that was equipped with mass spectrometer (Agilent, 5973N) (GC/MS) for further analysis. A capillary column (DM-5MS, $30 \times 0.25 \mathrm{~mm}$ ) was installed in the GC/MS and the base pressure for a mass detector was $\sim 1.0 \times 10^{-5}$ torr. The SPME fiber was inserted into the inlet of GC/MS and out-gassed at $250{ }^{\circ} \mathrm{C}$ until no GC/MS peak was detected before it was connected to the set-up for TPO experiments.

\section{Conclusions}

The Fe-oxide/ $/ \mathrm{Al}_{2} \mathrm{O}_{3}$ sample was prepared via a TR-CVD of Fe-oxide and subsequent annealing at $750{ }^{\circ} \mathrm{C}$. STEM-EDS, $\mathrm{XRD}$, and $\mathrm{N}_{2}$ adsorption/desorption analyses show an even distribution of $\mathrm{Fe}$ atoms on mesoporous $\mathrm{Al}_{2} \mathrm{O}_{3}$ implying the impregnation of Fe-oxide in mesoporous $\mathrm{Al}_{2} \mathrm{O}_{3}$. The effects of Fe-oxide impregnation into mesoporous $\mathrm{Al}_{2} \mathrm{O}_{3}$ on the decontamination of DMMP was investigated by exposing the two samples (Fe-oxide/ $\mathrm{Al}_{2} \mathrm{O}_{3}$ and bare $\mathrm{Al}_{2} \mathrm{O}_{3}$ ) to DMMP-containing dry air at room temperature.

At room temperature, molecular DMMP adsorption took place on both samples surface and the evolution of gaseous $\mathrm{CO}_{2}$ molecules was observed. The induction time of $\mathrm{CO}_{2}$ evolution (310 min) of Fe-oxide $/ \mathrm{Al}_{2} \mathrm{O}_{3}$ was significantly shorter than the case of bare $\mathrm{Al}_{2} \mathrm{O}_{3}(560 \mathrm{~min})$. Additionally, FT-IR analyses revealed that the dissociation of adsorbed DMMP molecules generating surface-bound MMP and methanol took place on the surface Fe-oxide/ $\mathrm{Al}_{2} \mathrm{O}_{3}$ samples after $360 \mathrm{~min}$ of DMMP exposure at room temperature. Those results indicated that DMMP degradation was promoted in the presence of dispersed Fe-oxide in mesoporous $\mathrm{Al}_{2} \mathrm{O}_{3}$.

TPO and GC/MS analyses that were conducted after $360 \mathrm{~min}$ of DMMP exposure at room temperature revealed the generation of gaseous methanol together with $\mathrm{CO}_{2}$ molecules from both samples surface at elevated temperature. For the case of Fe-oxide $/ \mathrm{Al}_{2} \mathrm{O}_{3}$ sample, the evolution of gaseous methanol was gradually increased with increasing temperature, but it soon ended at $300{ }^{\circ} \mathrm{C}$, and only the gaseous $\mathrm{CO}_{2}$ was generated at the temperature higher than $300{ }^{\circ} \mathrm{C}$ as a result of DMMP degradation. However, still, the significant amount of methanol was generated from the surface of bare $\mathrm{Al}_{2} \mathrm{O}_{3}$ sample, even at $400{ }^{\circ} \mathrm{C}$, and the gaseous methanol generation can be traced until the temperature reached to $600{ }^{\circ} \mathrm{C}$.

Our experimental observations indicated that the degradation of DMMP molecules on $\mathrm{Al}_{2} \mathrm{O}_{3}$ surface could be facilitated with the existence of Fe-oxide on $\mathrm{Al}_{2} \mathrm{O}_{3}$ surface, which can lower the minimum temperature for the total oxidation of $\mathrm{DMMP}$ into $\mathrm{CO}_{2}$. Additionally, these show a potential of mixed structure of Fe- and Al-oxides as a catalyst for the degradation of DMMP molecules in gas phase.

Supplementary Materials: The following are available online at http://www.mdpi.com/2073-4344/9/11/898/s1, Figure S1: Background subtracted FT-IR spectra of bare $\mathrm{Al}_{2} \mathrm{O}_{3}$ and Fe-oxide/ $/ \mathrm{Al}_{2} \mathrm{O}_{3}$ before and after 360 min of DMMP exposure at room temperature, Figure S2: GC/MS signal measured with Fe-oxide/ $\mathrm{Al}_{2} \mathrm{O}_{3}$ and mass spectrum of ambient air, Figure S3: GC/MS signal measure with bare $\mathrm{Al}_{2} \mathrm{O}_{3}$. 
Author Contributions: Conceptualization, T.G.W. and Y.D.K.; methodology, T.G.W., B.J.C.; validation, H.O.S. and Y.D.K.; formal analysis and investigation, T.G.W. and B.J.C.; data curation and draft preparation, H.O.S.; review and editing, H.O.S. and Y.D.K., Supervision, H.O.S. and Y.D.K.

Funding: This research was supported by Basic Science Research Program through the National Research Foundation of Korea (NRF) funded by the Ministry of Education (2017R1D1A1B03034381).

Acknowledgments: This research was supported by Basic Science Research Program through the National Research Foundation of Korea (NRF) funded by the Ministry of Education (2017R1D1A1B03034381). This research was supported by the Basic Science Research Program through the National Research Foundation of Korea (NRF) funded by the Ministry of Education(2018R1D1A1B07040916) and by a research grant from the Korea Basic Science Institute (D39613).

Conflicts of Interest: The authors declare no conflict of interest.

\section{References}

1. Mileson, B.E.; Chambers, J.E.; Chen, W.L.; Dettbarn, W.; Ehrich, M.; Eldefrawi, A.T.; Gaylor, D.W.; Hamernik, K.; Hodgson, E.; Karczmar, A.G.; et al. Common mechanism of toxicity: A case study of organophosphorus pesticides. Toxicol. Sci. 1998, 41, 8-20. [PubMed]

2. Pope, C.N. Organophosphorus pesticides: Do they all have the same mechanism of toxicity? J. Toxicol. Environ. Health Part B 1999, 2, 161-181. [CrossRef] [PubMed]

3. Picard, B.; Chataigner, I.; Maddaluno, J.; Legros, J. Introduction to chemical warfare agents, relevant simulants and modern neutralisation methods. Org. Biomol. Chem. 2019, 17, 6528-6537. [CrossRef] [PubMed]

4. $\quad$ Ekerdt, J.G.; Klabunde, K.J.; Shapley, J.R.; White, J.M.; Yates, J.T. Surface chemistry of organophosphorus compounds. J. Phys. Chem. 1988, 92, 6182-6188. [CrossRef]

5. Zhou, J.; Varazo, K.; Reddic, J.E.; Myrick, M.L.; Chen, D.A. Decomposition of dimethyl methylphosphonate on $\mathrm{TiO}_{2}$ (110): Principal component analysis applied to X-ray photoelectron spectroscopy. Anal. Chim. Acta 2003, 496, 289-300. [CrossRef]

6. Tzou, T.Z.; Weller, S.W. Catalytic oxidation of dimethyl methylphosphonate. J. Catal. 1994, 146, 370-374. [CrossRef]

7. O'Shea, K.E.; Beightol, S.; Garcia, I.; Aguilar, M.; Kalen, D.V.; Cooper, W.J. Photocatalytic decomposition of organophosphonates in irradiated $\mathrm{TiO}_{2}$ suspensions. J. Photochem. Photobiol. A Chem. 1997, 107, 221-226. [CrossRef]

8. Wilmsmeyer, A.R.; Gordon, W.O.; Davis, E.D.; Troya, D.; Mantooth, B.A.; Lalain, T.A.; Morris, J.R. Infrared spectra and binding energies of chemical warfare nerve agent simulants on the surface of amorphous silica. J. Phys. Chem. C 2013, 117, 15685-15697. [CrossRef]

9. Wilmsmeyer, A.R.; Uzarski, J.; Barrie, P.J.; Morris, J.R. Interactions and binding energies of dimethyl methylphosphonate and dimethyl chlorophosphate with amorphous silica. Langmuir 2012, 28, 10962-10967. [CrossRef]

10. Mitchell, M.B.; Sheinker, V.N.; Mintz, E.A. Adsorption and decomposition of dimethyl methylphosphonate on metal oxides. J. Phys. Chem. B 1997, 101, 11192-11203. [CrossRef]

11. Templeton, M.K.; Weinberg, W.H. Adsorption and decomposition of dimethyl methylphosphonate on an aluminum oxide surface. J. Am. Chem. Soc. 1985, 107, 97-108. [CrossRef]

12. Lin, S.T.; Klabunde, K.J. Thermally activated magnesium oxide surface chemistry. Adsorption and decomposition of phosphorus compounds. Langmuir 1985, 1, 600-605. [CrossRef]

13. Li, Y.X.; Schlup, J.R.; Klabunde, K.J. Fourier transform infrared photoacoustic spectroscopy study of the adsorption of organophosphorus compounds on heat-treated magnesium oxide. Langmuir 1991, 7, 1394-1399. [CrossRef]

14. Štengl, V.; Houšková, V.; Bakardjieva, S.; Murafa, N.; Mař́íková, M.; Opluštil, F.; Němec, T. Zirconium doped nano-dispersed oxides of Fe, Al and Zn for destruction of warfare agents. Mater. Charact. 2010, 61, 1080-1088. [CrossRef]

15. Tesfai, T.M.; Sheinker, V.N.; Mitchell, M.B. Decomposition of dimethyl methylphosphonate (DMMP) on alumina-supported iron oxide. J. Phys. Chem. B 1998, 102, 7299-7302. [CrossRef]

16. Mitchell, M.B.; Sheinker, V.N.; Tesfamichael, A.B.; Gatimu, E.N.; Nunley, M. Decomposition of dimethyl methylphosphonate (DMMP) on supported cerium and iron co-impregnated oxides at room temperature. J. Phys. Chem. B 2003, 107, 580-586. [CrossRef] 
17. Sheinker, V.N.; Mitchell, M.B. Quantitative study of the decomposition of dimethyl methylphosphonate (DMMP) on metal oxides at room temperature and above. Chem. Mater. 2002, 14, 1257-1268. [CrossRef]

18. Tang, X.; Hicks, Z.; Wang, L.; Ganteför, G.; Bowen, K.H.; Tsyshevsky, R.; Sun, J.; Kuklja, M.M. Adsorption and decomposition of dimethyl methylphosphonate on size-selected $\left(\mathrm{MoO}_{3}\right)_{3}$ clusters. Phys. Chem. Chem. Phys. 2018, 20, 4840-4850. [CrossRef]

19. Hung, W.-C.; Wang, J.-C.; Wu, K.-H. Adsorption and decomposition of dimethyl methylphosphonate (DMMP) on expanded graphite/metal oxides. Appl. Surf. Sci. 2018, 444, 330-335. [CrossRef]

20. Mera, N.; Hirakawa, T.; Sano, T.; Takeuchi, K.; Ichinose, H.; Seto, Y.; Negishi, N. Continuous elimination of gaseous dimethyl methylphosphonate by a photocatalytic flow reaction system. Appl. Catal. B Environ. 2014, 146, 71-78. [CrossRef]

21. Grandcolas, M.; Sinault, L.; Mosset, F.; Louvet, A.; Keller, N.; Keller, V. Self-decontaminating layer-by-layer functionalized textiles based on $\mathrm{WO}_{3}$-modified titanate nanotubes. Application to the solar photocatalytic removal of chemical warfare agents. Appl. Catal. A Gen. 2011, 391, 455-467. [CrossRef]

22. Rusu, C.N.; Yates, J.T. Adsorption and decomposition of dimethyl methylphosphonate on $\mathrm{TiO}_{2}$. J. Phys. Chem. B 2000, 104, 12292-12298. [CrossRef]

23. Panayotov, D.A.; Morris, J.R. Uptake of a chemical warfare agent simulant (DMMP) on $\mathrm{TiO}_{2}$ : Reactive adsorption and active site poisoning. Langmuir 2009, 25, 3652-3658. [CrossRef] [PubMed]

24. Jeong, J.H.; Kim, S.Y.; Kim, J.; Cha, B.J.; Han, S.W.; Park, C.H.; Woo, T.G.; Kim, C.S.; Kim, Y.D. Adsorption and oxidative desorption of acetaldehyde over mesoporous $\mathrm{Fe}_{\mathrm{x}} \mathrm{O}_{\mathrm{y}} \mathrm{H}_{\mathrm{z}} / \mathrm{Al}_{2} \mathrm{O}_{3}$. ACS Omega 2019, 4, 5382-5391. [CrossRef] [PubMed]

25. Hong, Y.; Cha, B.J.; Kim, Y.D.; Seo, H.O. Mesoporous $\mathrm{SiO}_{2}$ particles combined with Fe oxide nanoparticles as a regenerative methylene blue adsorbent. ACS Omega 2019, 4, 9745-9755. [CrossRef] [PubMed]

26. Templeton, M.K.; Weinberg, W.H. Decomposition of phosphonate esters adsorbed on aluminum oxide. J. Am. Chem. Soc. 1985, 107, 774-779. [CrossRef]

27. Dixon, J.R.; George, W.O.; Hossain, M.F.; Lewis, R.; Price, J.M. Hydrogen-bonded forms of methanol IR spectra and abinitiocalculations. J. Chem. Soc. Faraday Trans. 1997, 93, 3611-3618. [CrossRef]

(C) 2019 by the authors. Licensee MDPI, Basel, Switzerland. This article is an open access article distributed under the terms and conditions of the Creative Commons Attribution (CC BY) license (http://creativecommons.org/licenses/by/4.0/). 